\title{
FORMALNO-PRAWNA PROBLEMATYKA ARCHEOLOGII WSPÓLCZESNOŚCI W POLSCE
}

SŁowa KLuCzowe: broń, prawo, archeologia, współczesność, historia, zabytek KEYwORDs: weapon, law, archaeology, contemporary, history, artefact

Od pewnego czasu w środowisku archeologów obserwujemy dyskusje na temat zagadnień związanych z archeologią współczesności. Temat ten jest również przedmiotem sporów pomiędzy przeciwnikami i zwolennikami nowatorskiego spojrzenia na archeologię. Niektórzy, wywodzący się ze środowiska archeologów, umiejętnie odbiegają od tematu i twierdzą, że nie ma to nic wspólnego z archeologią, czasami wręcz odcinając się od problematyki. Słyszymy również głosy, i to wśród coraz większej grupy archeologów, że od tematyki tej nie uciekniemy. Wskazują oni, że ponieważ archeologia jest nauką otwartą, również przedmioty, które jeszcze niedawno były masowo produkowane mogą stać się ukrytym nośnikiem historii a co się z tym wiąże, tematem badań archeologów. Są to przede wszystkim artefakty odnajdywane obecnie w kontekście miejsc powiązanych z tragicznymi wydarzeniami naszych dziejów. Nie sposób się z nimi nie zgodzić, przemawia za tym bowiem coraz więcej argumentów. Pochylając się nad tym zagadnieniem warto zauważyć, że obszarem badań archeologów stają się coraz częściej miejsca i wydarzenia związane $\mathrm{z}$ historią współczesną. Zazębia się to $\mathrm{z}$ problemem, jakim są pojawiające się z różnych źródeł informacje o okradaniu i jednocześnie niszczeniu stanowisk archeologicznych wraz z licznie występującymi na terenie naszego kraju miejscami pól bitewnych. Z przykrością można stwierdzić, że proceder ten stał się dla niektórych stałym źródłem dochodu, a zagrożenia jakie przy tej okazji czyhają na dziedzictwo archeologiczne w Polsce, również współczesne, rosną do rangi olbrzymiego problemu. Skala tego zjawiska wciąż się nasila. Ma to związek z dynamicznie rosnącym popytem wśród kolekcjonerów na zabytki, dzieła sztuki i pamiątki kolekcjonerskie, zwłaszcza z okresu minionych kon- 
fliktów zbrojnych. Granice działania i zainteresowania poszukiwaczy, tak jak archeologia, również ewoluują. Poszukiwacze zabytków są głównie nastawieni na zysk i odnalezienie przede wszystkim przedmiotów nowożytnych, łatwych do spieniężenia. Podczas swoich eksploracji, prowadząc penetracje wykrywaczem metalu, nie mają pewności, co wydobędą na powierzchnię. Problemem w takich przypadkach jest także określenie, co należy zakwalifikować jako zabytek archeologiczny, a co nim nie jest. Ostatnio obserwujemy, iż problematyka ta oprócz klasycznie rozuminych stanowisk archeologicznych i pól bitewnych występuje również $\mathrm{w}$ miejscach związanych $\mathrm{z}$ martyrologią, na cmentarzach i mogiłach wojennych. Jest to związane $z$ nielegalnymi poszukiwaniami zabytków i ich obrotem. Służby konserwatorskie i archeolodzy, pomimo grożących za takie nielegalne działania sankcji karnych, nie są w stanie zapanować nad tym narastającym problemem. Wydaje się, że najwyższy czas pochylić się nad tym zagadnieniem zwłaszcza, że nie da się od niego uciec. Wskazane byłoby, wspólnie z archeologami, służbami konserwatorskimi i wszystkimi zainteresowanymi, wyjaśnić pojawiające się wątpliwości, jednocześnie wypracowując jedno stanowisko. Trzeba sobie uzmysłowić, że archeologia współczesności to badanie reliktów poprzednich wydarzeń, które nas otaczają i są obecne w naszej pamięci. To także materialne ślady naszej egzystencji, które po nas pozostaną i również mogą stać się przedmiotem badań następnych pokoleń.

Tematem artykułu jest między innymi przedstawienie zarysu zagadnień związanych z rozwijającą się archeologią, jej metodami badawczymi, której okres zainteresowania ewoluując staje się także narzędziem badawczym współczesnej historii jak i kryminalistyki. Analizę tę rozpocznę od przybliżenia istoty archeologii i nauk jej bliskich, która wprowadzi nas do poruszanego problemu archeologii współczesności. Podejmę ponadto próbę pokazania możliwości, które poprzez osiągnięcia archeologii przyczyniają się do podniesienia wartości dowodowej i prawidłowego ukierunkowania wiedzy historycznej lub doprowadzają do rozwiązania zagadki kryminalnej. Należy wspomnieć, że obecnie archeolodzy biorą udział w wielu projektach badawczych. Dzięki swoim umiejętnościom interpretacji poszerzają możliwości, rozpoznania nieznanych lub potwierdzenia znanych faktów z naszej historii. Naświetlone zostaną również podstawowe zagadnienia prawne oraz problemy, z jakimi boryka się współcześnie archeologia.

Gwałtowny rozwój archeologii datowany od pierwszej połowy XIX wieku wiąże się z prowadzonymi wówczas intensywnymi wykopaliskami na terenie Europy, Azji i Afryki (Renfrew, Bahn 2002: 21-25). Jednak już od XVII wieku widocznie wzrosło zainteresowanie pracami archeologicznymi (Ławecka 2003: 12-18). Duży wpływ na rozwój omawianej nauki miały osiągnięcia kształtującej się w owym czasie geologii. Ogromne znaczenie odegrały tutaj przede wszystkim zaawansowane obserwacje dotyczące stratyfikacji warstw skalnych, które 
stały się podstawą metodyki prac archeologicznych. O początkach archeologii jako dyscypliny naukowej możemy mówić dopiero od pierwszej połowy XIX wieku (Wrońska-Kowalska 1997: 315-317). Okres ten przypadał również na początki rozwoju kryminalistyki (Pływaczewski, Kędzierska 2001: 14).

Archeologia jest nauką zajmującą się wszystkimi pozostałościami działalności rąk ludzkich i bytności człowieka, które wywarły istotny wpływ na otoczenie i zostawiły swój ślad przez cały okres jego bytowania na danym obszarze (Gąssowski 1985: 7-10; Barker 1994: 8; Ławecka 2003: 5-7). Jej zadaniem jest odtwarzanie społeczno-kulturowej przeszłości człowieka na podstawie znajdujących się w ziemi, na ziemi i pod wodą materialnych pozostałości ludzkiej egzystencji. Bada wytwory ręki ludzkiej, ślady wpływów człowieka na środowisko naturalne oraz szczątki samych ludzi. Do chwili obecnej granica chronologiczna zainteresowania archeologii wielokrotnie ulegała przesunięciu. Wiązało się to $\mathrm{z}$ upływem czasu, rozwojem cywilizacji oraz następującymi, niewątpliwie burzliwie, zmianami społeczno-gospodarczymi.

Mówiąc o archeologii należy również wspomnieć o archeologii prawnej, nieco odmiennej od założeń klasycznie rozumniej archeologii, która jest nauką pomocniczą historii ustrojów państw i prawa sądowego, zajmującą się wyszukiwaniem i badaniem zabytków materialnych posiadających w przeszłości prawnie ustalony, instrumentalny charakter w stosunku do funkcji stanowienia i realizowania norm prawnych. Zasadniczym zadaniem archeologii prawnej jest wynajdywanie, inwentaryzowanie i interpretowanie zabytków, co w efekcie końcowym powinno dać zaklasyfikowanie tychże zabytków do odpowiednich szczebli systematyki, ustalenie czasu wprowadzenia ich do obiegu prawnego i czasu wyjścia z użycia. Określenie ich prawnych funkcji i zmian, jakie w tej dziedzinie występowały, wpływów i zapożyczeń typologicznych, za którymi mogły iść lub które mogły być spowodowane przez naleciałości pochodzące od innych systemów prawnych, wreszcie ustalenie rozprzestrzenienia się danego typu zabytku w aspekcie czasowym i terytorialnym (Maisel 1982: 33; 1989: 5-6). Cele te jednak realizowane są głównie przez prawników, badaczy historii ustroju państwa, nie mających bezpośredniego kontaktu z miejscem wyodrębniania dowodów ludzkiej egzystencji oraz wpływu na przebieg czynności na miejscu prowadzonych badań.

W ostatnich latach w Polsce wykształciła się i dynamicznie rozwija nowa dyscyplina naukowa zwana archeologią sadową lub archeologią kryminalistyczną. Jest ona połączeniem kryminalistyki, archeologii i medycyny sądowej, a jednym z jej podstawowych zadań jest prowadzenie wyspecjalizowanych ekshumacji, poszukiwanie miejsc zakopanych zwłok oraz ich wydobycie, oględziny i badanie terenu po katastrofie (Kawecki i in. 2013). Jest to niewątpliwie związane z podobieństwami oraz wzajemnym powiązaniem archeologii i kryminalistyki. Obie dziedziny nauki zajmują się badaniem działalności człowieka. Mają 
wspólne pole zainteresowania. Przedmiot badań leżący w zakresie kryminalistyki jest zawężony do działalności związanej z czynem zabronionym. Podstawowym źródłem informacji, w odniesieniu do zabytków archeologicznych, są zakodowane w nich komunikaty z przeszłości, które trzeba odczytać. Temu celowi służy przede wszystkim autopsja (Maisel 1989: 11). Wnioskowanie na podstawie ujawnionych śladów w miejscu mającym związek z przestępstwem jest bardzo zbliżone, a nawet identyczne $\mathrm{z}$ rozumowaniem i oceną śladów przeprowadzanymi przez archeologa. Odpowiedź na pytanie, kiedy i w jakich okolicznościach powstało zjawisko, z którego pozostałościami mamy do czynienia podczas badania, należy do podstawowych zadań archeologii i kryminalistyki (Gąssowski 1985: 7-8; Mamzer 2004: 62). Przedstawiciele obydwu zawodów posługują się podobnymi narzędziami do eksploracji i zabezpieczenia śladów, ponadto $\mathrm{w}$ zbliżony sposób prowadzone są przez nich oględziny. Ich celem jest zebranie maksymalnej ilości istotnych informacji o zdarzeniu i jego sprawcy. Informacje te zawarte są przede wszystkim $\mathrm{w}$ ujawnionych i zabezpieczonych śladach oraz w dokumentacji poglądowej. Celem wszelkiej dokumentacji sporządzonej w trakcie wykopalisk jest umożliwienie utrwalenia i odtworzenia pozyskanych danych. Jak widać, cele każdej z tych nauk są zbieżne, jednak archeologia sądowa, to moim zdaniem już kryminalistyka, która na swoje potrzeby wykorzystuje doświadczenia z archeologii. Należy sobie uzmysłowić, że badania archeologiczne są metodą pozyskiwania źródeł dla poznania historii również tej najnowszej, natomiast zainteresowania badawcze archeologii nie są ograniczone w czasie. Sama definicja zabytku archeologicznego, która przez to że jest zbyt otwarta, czasami jest zalążkiem stanowiącym podstawę dyskusji. Najczęściej dochodzi do niej podczas interpretacji odkrytego zabytku, będącego pozostałością historii najnowszej. To, iż archeologia zajmuje się okresem od epoki kamienia po czasy współczesne w niektórych sytuacjach jest problemem. Zgodnie z art. 3 pkt 1 ustawy o ochronie zabytków i opiece nad zabytkami mianem zabytku określa się nieruchomość lub rzecz ruchomą, jej części lub zespół, będące dziełem człowieka lub związane z jego działalnością i stanowiące świadectwo minionej epoki bądź zdarzenia, których zachowanie leży w interesie społecznym ze względu na posiadaną wartość historyczną, artystyczną lub naukową (Ustawa z dnia 23 lipca 2003 r. o ochronie zabytków i opiece nad zabytkami, Dz.U. Nr 162, poz. 1568). Analogicznie, zabytek ruchomy jest rzeczą ruchomą, jej częścią lub zespołem rzeczy ruchomych, których zachowanie leży w interesie społecznym ze względu na posiadaną wartość historyczną, artystyczną lub naukową. Określeniem zabytek archeologiczny nazywany jest zabytek nieruchomy, będący powierzchniową, podziemną lub podwodną pozostałością egzystencji i działalności człowieka, złożoną z nawarstwień kulturowych i znajdujących się w nich wytworów, bądź ich śladów albo zabytek ruchomy, będący tym wytworem (art. 3 pkt 4 u.o.z). Natomiast badaniami archeologicznymi określamy działania mające na celu odkry- 
cie, rozpoznanie, udokumentowanie i zabezpieczenie zabytku archeologicznego (art. 3 pkt 11 u.o.z.). W przypadku prowadzenia badań na stanowiskach nowożytnych jak również pradziejowych, wielokrotnie pojawiają się rzeczy i obiekty, które wymuszają konieczność modyfikacji metody badawczej i innego podejścia do problematyki. Są to okopy i transzeje, a także umocnienia z czasów działań wojennych. Znajdowane w trakcie badań archeologicznych militaria i przedmioty będące wyposażeniem żołnierza czy numizmaty mogą stanowić zabytki zgodnie z art. 3 pkt 4 u.o.z. Koniecznie trzeba zawrócić uwagę, iż to właśnie numizmaty i militaria oraz elementy wyposażenia żołnierskiego są, poza fragmentami ceramiki, jednymi z najczęściej odkrywanych ruchomych zabytków archeologicznych. Umocnienia z czasów działań wojennych, miejsca zagłady ludności cywilnej lub oddziałów zbrojnych, jak również groby są niewątpliwie przestrzeniami, z których właśnie z udziałem archeologów można wydobyć mnóstwo cennych informacji. Odrębną kwestię, co wielokrotnie jest podnoszone podczas dyskusji, stanowi kwalifikacja przedmiotów pochodzących z okresu II wojny światowej, również będących zabytkami. Coraz częściej, głównie poprzez zainteresowanie kolekcjonerów, stają się one przedmiotem przestępczej działalności poszukiwaczy zabytków. Znajdując się pod powierzchnią ziemi, także posiadają ścisłe powiązanie z nawarstwieniem kulturowym, wpisując się w prawną definicję zabytku archeologicznego. Każdy przypadek takiego znaleziska, moim zdaniem, należy poddać oddzielnej analizie. Osobami posiadającymi kompetencje do kwalifikacji tych przedmiotów jako zabytki archeologiczne są przede wszystkim konserwatorzy zabytków i archeolodzy specjalizujący się w badaniach danego okresu. Nie mogą to być poszukiwacze, ponieważ wielokrotnie poza pojedynczymi przypadkami, nie mają do tego odpowiedniego wykształcenia lub wiedzy. Można jednak stanowczo stwierdzić, iż wzrastające zainteresowanie kolekcjonerów poszukiwaniem militariów stanowi poważne zagrożenie dla materialnych pozostałości historii czasów I i II wojny światowej, a nawet okresów późniejszych, które coraz częściej jest dostrzegane przez służby konserwatorskie (Ogrodzki 2010: 9-10). Proceder z tym związany ma znamiona czynu zabronionego i w żaden sposób nie jest powiązany z badaniami archeologicznymi ani ekshumacjami. Należy ponadto zauważyć, że archeologia, jak wiele innych nauk, ewoluuje. Zakres jej zainteresowań wciąż się przesuwa. Jest to związane z upływem czasu oraz dynamicznymi wydarzeniami, które towarzyszyły naszemu krajowi przez ostatnie stulecie. Zmieniająca się sytuacja polityczna oraz zainteresowanie historią naszych czasów nie kończy się na I i II wojnie światowej. Potrzeba korygowania źródeł historycznych i nadpisywania białych plam dotyczących przeszłości naszego narodu powoduje, iż archeologia coraz częściej potrafi przez swoje badania dopisywać lub wyjaśniać niedopowiedziane elementy historycznej układanki. Coraz częściej pole zainteresowania archeologów dotyka mrocznego okresu działania na terenie naszego kraju niemieckich władz okupacyjnych 
i powojennych władz komunistycznych. Należy pamiętać, że nawet trudna historia związana z dziejami naszego narodu wymaga ochrony. Jest to również nasze dziedzictwo, które z jego materialnymi i niematerialnymi elementami bez ograniczeń podlega ochronie zapisanej w art. 5 Konstytucji Rzeczypospolitej Polskiej. Artykuł ten stanowi, iż Rzeczpospolita Polska strzeże niepodległości i nienaruszalności swojego terytorium, zapewnia wolności i prawa człowieka i obywatela oraz bezpieczeństwo obywateli, strzeże dziedzictwa narodowego oraz zapewnia ochronę środowiska, kierując się zasadą zrównoważonego rozwoju (Konstytucja Rzeczypospolitej Polskiej z dnia 2 kwietnia 1997, Dz.U. 1997 Nr 78, poz. 483; Trzciński 2010: 38-40). Właśnie zapis stanowiący, iż Państwo strzeże dziedzictwa narodowego nakłada obowiązek zapewnienia ochrony między innymi poprzez stworzenie odpowiednich ku temu warunków. Wyrażone jest to we wprowadzonych przez ustawodawcę aktach prawnych, których celem jest zapewnienie przede wszystkim ochrony nad dobrami kultury. Wchodzą w to wybrane przepisy zawarte w kodeksie karnym, w tym również karne ustawy o ochronie zabytków i opiece nad zabytkami. Stanowią o tym między innymi normy prawne zabraniające prowadzenia nielegalnych prac poszukiwawczych bez pozwolenia konserwatora zabytków, niszczenia lub uszkodzenia zabytków, nielegalnego wywozu za granicę. Do tego należy dodać przepisy kodeksu karnego nakładające wysokie sankcje karne na osoby okradające lub znieważające miejsca pochówków, jak również znieważające bądź niszczące pomniki lub miejsca upamiętniające wydarzenia historyczne. Takie założenia ma również ustawa o Instytucie Pamięci Narodowej chroniąca dokumenty stanowiące dowody zbrodni przed ukryciem lub zniszczeniem (Ustawa z dnia 18 grudnia $1998 \mathrm{r}$. o Instytucie Pamięci Narodowej - Komisji Ścigania Zbrodni przeciwko Narodowi Polskiemu, Dz.U. 1998 Nr 155, poz. 1016; Ustawa z dnia 6 czerwca 1997 r. kodeks karny, Dz.U. z 1997 r. Nr 88, poz. 553; Ustawa z dnia 23 lipca 2003 r. o ochronie zabytków i opiece nad zabytkami, Dz.U. Nr 162, poz. 1568; Trzciński 2010: 49-72). Art. 35 ust. 1 i 2 ustawy o ochronie zabytków i opiece nad zabytkami stanowi wprost, iż znalezione lub odkryte przedmioty, będące zabytkiem archeologicznym należą do Skarbu Państwa. W związku z tym przedmioty te wyłączone są również z obrotu handlowego. Zgodnie z zapisem art. 189 kodeksu cywilnego i zmianami jakie wprowadzone zostały w 2015 roku przez ustawę o rzeczach znalezionych w przypadku gdy rzecz nie będąca zabytkiem, materiałem archiwalnym znaleziona $\mathrm{w}$ takich okolicznościach, że poszukiwanie właściciela byłoby oczywiście bezcelowe, staje się przedmiotem współwłasności w częściach ułamkowych znalazcy i właściciela nieruchomości, na której rzecz została znaleziona (Ustawa z dnia 20 lutego 2015 r. o rzeczach znalezionych, Dz.U. 2015, poz. 397; Ustawa z dnia 23 kwietnia 1964 r. kodeks cywilny, Dz.U. $1964 \mathrm{Nr} 16$, poz. 93). W takim wypadku znaleziony przedmiot, który nie jest zabytkiem, obciążony jest prawami własności innych osób. W tym samym artykule 
ustawodawca dodaje, iż w przypadku gdy rzecz ta jest zabytkiem lub materiałem archiwalnym, staje się ona własnością Skarbu Państwa, a znalazca jest obowiązany wydać ją niezwłocznie właściwemu staroście. Nowa ustawa doprecyzowała sporną kwestię roszczeń dotyczących przedmiotów znalezionych, posiadających cechy zabytku. Jak już wcześniej zostało stwierdzone, rzeczy będące zabytkami to takie, które spełniają definicję stypizowaną w ustawie o ochronie zabytków i opiece nad zabytkami. Jednak największe kompetencje do rozstrzygnięcia tego problemu w przypadku ich znalezienia lub odkrycia posiada przede wszystkim konserwator zabytków, a nie znalazca. W tym momencie ponownie powraca kwestia definicji zabytku i zabytku archeologicznego, która przez to że jest zbyt otwarta stanowi czasami podstawę gorącej dyskusji. Niewątpliwie największe problemy nastręcza interpretacja zabytku stanowiącego pozostałość historii najnowszej. W definicji zabytku nie ma cenzusu czasowego, a jedynie stwierdzenie, że zabytek stanowi świadectwo minionej epoki bądź zdarzenia. Jest to niedookreślony zwrot językowy, który zostaje skonkretyzowany w procesie stosowania prawa. Ponadto, w definicji znajdujemy odwołanie do interesu społecznego ponieważ jego zachowanie musi leżeć w interesie społecznym (Wyrzykowski 1986; Żurawik 2013: 57). W procesie uznawania rzeczy za zabytek konieczne jest odwołanie się do wartościowania, tak więc niezbędne jest wykazanie co najmniej jednej z reprezentowanych przez zabytek wartości: historycznej, artystycznej lub naukowej (Zeidler 2008: 173; Zalasińska, Zeidler 2012: 243). Analizując powyższe definicje można powiedzieć, że przedmioty stanowiące relikty ważnych dla naszego narodu wydarzeń, również te współczesne, wpisują się w definicje zabytku i zabytku archeologicznego. Są to zazwyczaj nośniki informacji kryjące mroczne fragmenty naszej historii, czasami świadomie zacierane lub ukryte. Należy tutaj nadmienić, że miejsca pochówków poległych żołnierzy, tak jak cmentarzyska z minionych epok, również posiadają cechy zabytku i stanowią źródło informacji. Ten sam problem dotyczy także miejsc o szczególnym znaczeniu dla kultury, którymi mogą być pola bitew, starć zbrojnych i cmentarzyska wojenne, łącznie z miejscami martyrologii z różnych okresów historycznych (Gadecki 2014: 41). Obie definicje wpisują się w relikty współczesnych nam wydarzeń bądź przedmiotów z nimi związanych. Znajdowane w trakcie odkryć i poszukiwań militaria i przedmioty będące, oprócz rzeczy osobistych, wyposażeniem żołnierza mogą stanowić zabytki zgodnie z art. 3 ustawy o ochronie zabytków i opiece nad zabytkami.

Podsumowując swoje rozważania uważam, że archeologia współczesności to nic innego jak ciąg dalszy archeologii, która ewoluuje i podąża za człowiekiem wraz z jego skomplikowaną niekiedy egzystencją. To nadal archeologia, która $\mathrm{z}$ uwagi na okres, jaki jest $\mathrm{w}$ jej zainteresowaniu nazywana jest obecnie archeologią współczesności. Niewątpliwie jednak, za kilkaset lat również ona $\mathrm{z}$ uwagi na mijający czas oraz nowe, czasami dynamicznie przebiegające prze- 
miany społeczno-gospodarcze będzie miała swoje nazewnictwo. Być może się to zmieni w przypadku, gdy ustawodawca wprowadzi do definicji zabytku archeologicznego cenzus czasowy. Wydaje się, że odsuwanie się od problemu i kwestionowanie rozwoju archeologii jest niejako zaprzeczaniem i negowaniem całej nauki. Nauki, jaką jest archeologia, której zadania polegają na próbie odkrywania przeszłości poprzez umiejętne rozkodowanie nośników informacji, jakimi są odkopane przedmioty oraz towarzyszące im odkryte źródła nieruchome. Dąży ona do rozpoznawania faktów z historii przy użyciu swoich doświadczeń oraz nowoczesnych technologii. Potrafi umiejętnie wykorzystać do swoich badań osiągnięcia z innych nauk oraz udokumentować ich wyniki, w taki sposób, aby pozostało to jednoznaczne i czytelne dla potomnych. Należy pamiętać, że archeologia współczesności jest również niezwykle ważnym elementem w kształtowaniu świadomości kulturowej, co dodatkowo podnosi jej wartość.

Adam Grajewski

Komenda Główna Policji

e-mail: adam.ggg1@wp.pl

\section{Bibliografia}

\section{Źródła}

Konstytucja Rzeczypospolitej Polskiej z dnia 2 kwietnia 1997 r. (Dz.U. 1997 Nr 78, poz. 483).

Ustawa z dnia 23 kwietnia 1964 r. kodeks cywilny (Dz.U. 1964 Nr 16, poz. 93).

Ustawa z dnia 6 czerwca 1997 r. kodeks karny (Dz.U. z 1997 r. Nr 88, poz. 553).

Ustawa z dnia 18 grudnia 1998 r. o Instytucie Pamięci Narodowej-Komisji Ścigania Zbrodni przeciwko Narodowi Polskiemu (Dz.U. 1998 Nr 155, poz. 1016).

Ustawa z dnia 23 lipca 2003 r. o ochronie zabytków $i$ opiece nad zabytkami (Dz.U. $\mathrm{Nr} 162$, poz. 1568).

Ustawa z dnia 20 lutego 2015 r. o rzeczach znalezionych (Dz.U. 2015, poz. 397).

\section{Opracowania}

Barker P. (1994), Techniki wykopalisk archeologicznych, Biblioteka Muzealnictwa i Ochrony Zabytków, Warszawa.

Gadecki B. (2014), Ustawa o ochronie zabytków i opiece nad zabytkami. Art. 108-120. Przepisy karne, C.H. Beck, Warszawa.

Gassowski J. (1985), Kultura pradziejowa na ziemiach Polski, Państwowe Wydawnictwo Naukowe, Warszawa.

Kawecki J., Konczewski P., Szwagrzyk K., Trzciński M. (2013), Archeologia sądowa w teorii i praktyce, Wolters Kluwer, Warszawa.

Ławecka D. (2003), Wstęp do archeologii, Państwowe Wydawnictwo Naukowe, Warszawa-Kraków. 
Maisel W. (1982), Archeologia prawna Polski, Państwowe Wydawnictwo Naukowe, Warszawa-Poznań.

Maisel W. (1989), Archeologia prawna Europy, Państwowe Wydawnictwo Naukowe, Warszawa-Poznań.

Mamzer H. (2004), Archeologia i dyskurs, IAE PAN, Poznań.

Ogrodzki P. (2010), Przestępczość przeciwko zabytkom, krótka charakterystyka problemu. Stan na rok 2010, [w:] R. Pasieczny (red.), Cenne, bezcenne/utracone, NIMOZ, Warszawa, s. 9-10.

Pływaczewski W., Kędzierska G. (2001), Leksykon Policyjny, WSPol, Szczytno.

Renfrew C., Bahn P. (2002), Archeologia, Prószyński i S-ka, Warszawa.

Trzciński M. (2010), Przestępczość przeciwko zabytkom archeologicznym. Problematyka prawno-kryminalistyczna, Wolters Kluwer Polska, Warszawa.

Wrońska-Kowalska J. (1997), Recepcja osiagnięć archeologii europejskiej w badaniach nad epoka kamienia, [w:] M. Głosek (red.), Archeologia i starożytnicy, IAiE PAN, Łódź, s. 315-317.

Wyrzykowski M. (1986), Pojęcie interesu spolecznego w prawie administracyjnym, Wydawnictwo Uniwersytetu Warszawskiego, Warszawa.

Zalasińska K., Zeidler K. (2012), Problematyka wartościowania jako podstawy rozstrzygnięć wojewódzkiego konserwatora zabytków, [w:] B. Szmygin (red.), Wartościowanie w ochronie i konserwacji zabytków, Wydawnictwo Politechniki Lubelskiej, Warszawa-Lublin.

Zeidler K. (2008), O znaczeniu i roli teorii konserwatorskiej w procesie stosowania prawa, [w:] B. Szmygin (red.), Współczesne problemy teorii konserwatorskiej w Polsce, Wydawnictwo Politechniki Lubelskiej, Warszawa-Lublin.

Żurawik A. (2013), ,, Interes publiczny”, ,, interes społeczny” $i$,, interes społecznie uzasadniony”: Próba dookreślenia pojęć, „Ruch Prawniczy, Ekonomiczny i Socjologiczny", t. $75, \mathrm{nr} 2$.

\section{SUMMARY}

\section{FORMAL LEGAL PROBLEMS OF CONTEMPORARY ARCHEOLOGY IN POLAND}

Recently, in the circle of archaeologists, we observe discussions on the issues related to the contemporary archeology. This topic is also the subject of disputes between the opponents and the supporters of an innovative look at archeology. Studying this issue, it is worth pointing that the places and events connected with the contemporary history are increasingly becoming a subject of interest to archaeologists. It overlaps with another issue - devastation and destruction of archaeological sites along with many places of battlefields in our country. It is increasingly evident that the field of action of archaeologists touches the dark period of operation in our country by the German occupation authorities and the post-war communist authorities. We should keep in mind 
that even the dark part of our history must be protected. It is also our heritage, which should be a subject of protection enshrined in the Constitution of the Polish Republic with its tangible and intangible elements and without any restrictions. It would be advisable that the archaeologists, conservation authorities and all stakeholders should explain all the emerging doubts while working out on the common position in this matter. We should realize that the contemporary archeology is not only traces of the past events that surround us, but it is also the material evidence of our existence that will remain after us. It seems that the contemporary archeology is nothing but a continuation of the archeology, which evolves and follows the mankind, along with our sometimes complicated existence. It is still archeology, which is called the contemporary archeology in order to precisely define the period of its interest. We should keep in mind that the contemporary archeology is also an important element shaping the cultural awareness which further increases its value. 